\title{
Sensed fittingness between act and consequence: The last acts of Esther in the book of Esther and Grace in the film Dogville
}

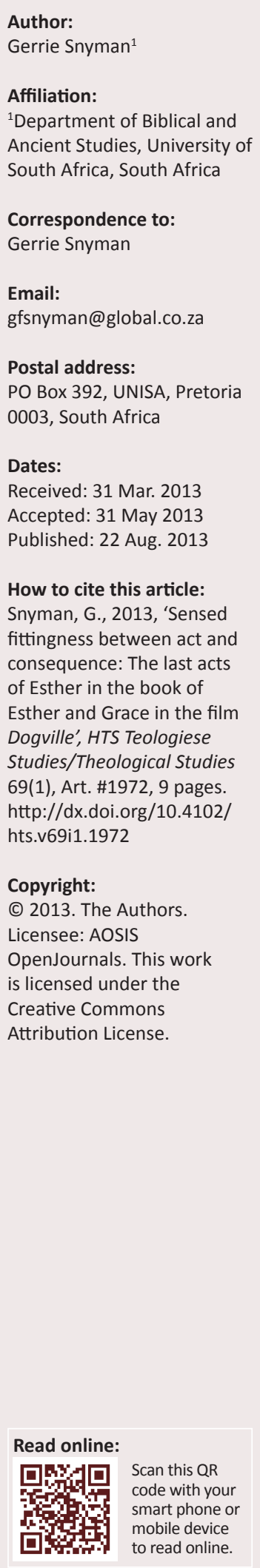

The book of Esther employs a wisdom theme to develop the plot and its denouement. The particular illustration of wisdom is that of role reversal. Haman, the second in command, gets kicked out and the leaders of those he sought to lock out filled his position. However, the role reversal becomes more than a mere change in status. As Grace needed to step into her gangster father's shoes in the film Dogville in order to achieve justice, so Esther had to step into Persian shoes to achieve justice. The execution of justice is an untidy and messy affair. The question this article puts on the table is whether Esther acts with justice in her quest for retribution. In answering this question, the article firstly inquires into the narrative rationality of the story and the denouement of the plot. Related to the book of Esther's narrative rationality, the article examines the question of wisdom from a narrator's and character's perspective. Lastly, it will then put the issue of justice on the table with the help of the film Dogville in order to see whether there is a link between wisdom and justice.

\section{Introduction}

Is the pleasure of reading the book of Esther the pleasure of gratified anger? Or perhaps the pleasure of Schadenfreude, the satisfaction experienced by the wounded and the resentful? Is it a gratification enjoyed by a civilised reader, or imaginably that of a barbarian? Does the book exhibit the realm of morality, goodness and justice, or should one simply argue that in terms of survival, the book cannot deal with morality?

These questions were not really asked about the book of Esther; they are in fact based on remarks by someone who saw the film Dogville (2004). That film tells the story of a young woman who flees from her gangster father and then accidentally discovers a small town called Dogville where she gets exploited by an economy of desire that has led to brutality, degradation and imprisonment. The film ends with the young woman, called Grace, enacting a choice - retribution in terms of annihilating the entire town except for the dog called Moses, which becomes in the end an allusion to the Mosaic Torah and its concept of (rough?) justice.

The viewer argues his reaction as follows:

Of course, seeing the film, I may have felt simply the pleasures of gratified anger, the pleasure of the wounded and the resentful, at seeing an accusation clearly made and harsh justice delivered against society. Was my pleasure the pleasure of a civilised man, or the pleasure of a barbarian; or, inevitably, both? (Garrett 2004)

The point of comparison between the book of Esther and Dogville is that despite the fact that evil gets its just deserts in the end in both stories, the question remains of whether the executioner of justice did not become evil herself. The two main characters' settings are vastly different. Esther operates in the royal court and Grace comes from a gangster background from which she flees, landing in the small rural community of Dogville. Moreover, the logic of good reasons for their respective actions cannot be matched. Esther operated from an individual superior position, although her people had become suppressed and were under threat of extinction, whilst Grace operated from the beginning from a position of exploitation and oppression. The act of retribution in both stories nevertheless invokes the question of justice. Both are exceptional women who are portrayed as 'ideal' versions of humanity, so that when they are wronged, it is more a reflection on the state of the human condition than anything else.

With Esther it is particularly the second day's request that becomes problematical, given that success has already been achieved on the first day of defence, or perhaps even earlier when Haman is unmasked and hanged on the gallows he constructed for Mordecai. With Grace in Dogville, in contrast to Esther's case, the question of justice and retribution is not that easy to 
answer, because it seems that in order to execute justice, the executioner becomes what the executed symbolised.

The article deals with the question of whether Esther acts with justice in her request for retribution. The answer is sought within the concept of traditional wisdom in ancient Israel. James Alfred Loader sees the book of Esther as rich in wisdom themes, to the extent that he would concede to the possibility mooted by Shemaryahu Talmon, that the story of Esther is a historicised wisdom tale (Loader 1992:223). Loader's main argument apart from the plethora of wisdom motifs in the book is the role reversal and the correspondence with the Joseph story, a point raised by Gerhard von Rad (1953). The correspondence between the Joseph story and the story of Esther is, according to Loader (1992:224), quite significant, in that it is 'fest in das Muster der Umkehrung integriert, das sie mit der Weisheitsliteratur teilen. Damit finden die weisheitlichen Elemente beider Erzählungen so wie ihre Parallelen eine Erklärung.'

In answering this question, the article firstly inquires into the narrative rationality of the story and the denouement of the plot. Related to its narrative rationality, the article examines the question of wisdom in the book of Esther from the narrator's and the character's perspective. Lastly, it puts the issue of justice on the table with the help of the film Dogville to determine whether there is a link between wisdom and justice.

\section{Narrative rationality}

Over against Western theology's rational-world paradigm ${ }^{1}$, ancient Israelite and Jewish sages tend to present their beliefs in story, poem, instruction and saying. Within what is called the 'narrative paradigm' (Fisher 1987:24) human beings are regarded inherently as storytellers. ${ }^{2}$ The basic premise is that a story provides valid reasons to be accepted. These reasons need not be persuasive, but they should warrant a belief, an action, or an attitude (Fisher 1987:107). With warrant, one should think in terms of something that sanctions, authorises, or justifies a particular action, disposition, or opinion. Reasons are valid when linked to values whose significance lie in their relevance, consistency, and consequence - in the story's trustworthiness and reliability. Moreover, the plot becomes an important factor in deciding whether a story provides good reasons to follow the advice fostered in the narrative.

What is it then that draws the reader to the story of Esther? Are the values and norms of ancient Israelite (early Second Temple Period) society not rather off-putting? Can one counter genocide with genocide? It seems that genocide is only a problem to the author when the target is his own

1.Walter Fisher (1987:59-62) regards it as a paradigm in which the human being acts as a rational being and where the world is a logical puzzle to be solved by appropriate analysis and the application of reason. The preponderance of narrative and its utilisation by narrative theologians led Leo Perdue (1994:325) to argue that narrative theologians remind the exegete of the fact that stories actualise meaning. narrative theologians remind the exegete of the fact that stories actualise meaning. It is when Christian theology analyses these (biblical?) in terms of a rational, these stories occur.

2.Fisher (1987:63) refers to homo narrans as the main metaphor for the narrative paradigm. Stories are meant to give order to human experience and to induce others to dwell in them in order to establish ways of living that will, in turn, confirm the story that constitutes one's life. people. For the Persians, genocide is their just deserts. The ancient world with its customs and traditions is far removed from contemporary readers' world, but certain vestiges of behaviour still have the ring of truth to these readers, because they may have similar experiences, for example, the role patriarchy plays in the story. In what way is it possible for the readers to identify with the story, the values and norms embedded in the story and the characters? The authoritarian character of patriarchy inevitably leads to violence, which Esther utilises to the advantage of her people. Does the story need these values? How would the story have sounded without them? Would there have been a story? Is retributive violence acceptable as a means of solving conflict? Or should one look deeper, to an underlying structure provided by an argument from wisdom, for example order versus chaos? Are the actions of Esther in Chapter 9 wise and necessary (in compliance with the imperative of order) or vindictive and bloodthirsty (thus conforming to the results of chaos)?

Reasons are produced and received within a particular historical and cultural framework. It is possible that reasons that were good at the time of the text was produced, are no longer valid at the time of text reception. On the one hand, from a Jewish perspective the book of Esther legitimises a religious celebration where a group of people succeeded in averting danger with the help of various mechanisms. Within Judaism, the story remains a legitimation for Purim (cf. Greenstein 1987:225-243).

On the other hand, a Christian perspective does not need Purim, so that the focus shifts to the obscurity of the deity and his providence in the history of the Jewish people. Although the story is not about the deity, its presence is felt whilst the human actors manoeuvre the events to achieve a certain outcome. His actions are veiled, as if he is standing in the wings applauding the events unfolding on the human stage.

But do we have good reasons to retell the story of Esther so many centuries later? If one has good reasons to retell the story today, the question remains whether there are good reasons to adhere to the advice fostered in the text, especially if that advice is taken too literally. For example, the character of Esther seems at first very compliant, doing what Mordecai expects of her by going to the harem and then doing what Hegai expects from her. However, once she becomes queen and Haman's pogrom is declared, Esther does not seem too eager to help Mordecai to solve the problem. Eventually she does, and reveals the conspiracy to the king. In the denouement of the story, she first asks the king for the right to self-defence, and then, on the second day, she requests a repetition as well as the public hanging of the corpses of the ten sons of Haman. The question relating to this second request, namely whether she is wise or vindictive, pertains to the problem of coherency: is she acting in line with what the story has so far constructed as her character? If her action is probable, the story may continue to lead the readers to adhere to the advice fostered in the text, but if it is decided the request for a second day makes her character incoherent, then the readers may find the advice fostered in the text less credible. 
From a narrative perspective the world in which a story takes place can either be a good, ordered one or a bad, chaotic or disordered one (Deist 1986:97; cf. Bremond 1980). Subsequently, the plot in the story is built around the movement between these two worlds or within one particular world. Mordecai and Haman appear to stay within one world - albeit each in a different one. Mordecai, with his apparent wisdom, remains within the ordered world and Haman, with the obstacles he puts in Esther's way, remains in the chaotic world.

In most of the Old Testament it seems that the plot provides reward for good deeds and punishment for bad deeds. Linking up with this scheme, Loader (1986:110) argues that wisdom gives its own stamp in terms of retribution. If a person obeys the rules of wisdom, God's authority is recognised and one participates in the good order God created. Such a person is regarded as wise and he or she is ultimately rewarded for his or her wisdom with success or prosperity. If someone disregards the rules of wisdom, that is, threatening the power of God and not turning away from evil ways, such a person is deemed to be opposing God's created order and subsequently lives in a chaotic world where foolishness reigns and the reward is failure and adversity. Such a person is regarded as a fool and receives punishment (cf. Loader 1986:104-106). Thus Mordecai in the end receives a reward by taking up Haman's powerful position and Haman, in turn, is hanged on the gallows he built for Mordecai.

With Haman removed from the scene, one would expect the story to end. But the addition to the plot here suggests that equilibrium has not been achieved yet. There is still fighting and resistance with the ten sons of Haman alive. They then become the next obstacle to be removed. The story does not say why they should be removed too, but given the genealogical link to Amalek and the latter's role in Israelite history, the reader may think that the 10 sons might continue Amalek's legacy and keep on pestering those related to Israel in some way or the other. If one follows this line of thought, Esther would then be wise to pursue the ten sons and make sure they will never bother her people again.

The reward for services rendered (Mordecai's elevation to the position of Haman) and the vengeance directed against a wrong incurred (the removal of Haman and his sons) constitute the two faces of retribution. Is the retribution in this story as the denouement of a particular plot the consequence of a wisdom point of view that lies implicit in the story, that is, the reversal of roles? Moreover, is retributive violence acceptable as a means of solving conflicts?

\section{Wisdom in the book of Esther Esther and wisdom}

In tandem with Loader's positive evaluation of the link between Esther and wisdom, Joseph Blenkinsopp (1995:43) argues that the book of Esther 'provides a perfect illustration of the sages' teaching on retribution. ${ }^{3}$ In his view, the author made use of 'procedures and themes familiar to the teachers of wisdom'. The book of Esther is therefore not necessarily a peculiar wisdom text such as Proverbs, but the author would have made use of wisdom features, for example in linking acts and consequences (Blenkinsopp 1995:46). ${ }^{4}$

In contrast to this positive view stand the views of James Crenshaw (1995) and Roger N. Whybray. Whybray (1968:528) does not accept that the Joseph story is 'a novel of genius belonging to the category of wisdom literature' because of its already existing role within the documentary hypothesis. On a more cautionary note, Whybray (1974:2) warns against seeing wisdom everywhere in the Old Testament as it makes the word 'wisdom' useless. Whybray (1974:3) warns that the interests of the scholarly community are not served when the word 'wisdom' is applied to every manifestation of an ability to use one's brain. ${ }^{5}$

Crenshaw (1995:312) states that Gerhard von Rad's article on the Joseph narrative is 'almost directly responsible for similar claims of wisdom influence upon Esther.' In applying 'methodological stringency' (cf. Gordon 1995:96), he concludes that the excitement led to 'exaggerated claims supported by dubious arguments and assumptions' such as those of Shemaryahu Talmon (1963:426), whom Loader thinks may have a point in defining the Esther book as 'a historicized wisdom-tale.' Talmon (1963) assumes the existence of a wisdom nucleus and describes the book as:

an enactment of standard 'Wisdom' motifs which are present also in other biblical narratives of a similar nature, and which biblical literature has in common with Ancient Near Eastern Wisdom literature, as defined by the literary-type analysis. (p. 429)

Crenshaw (1995:323) takes umbrage at Talmon, challenging his arguments as 'misstatements of fact or erroneous conclusions.' His rejection of wisdom in the book of Esther is based on Talmon's essay and his refuting of Talmon's claims. For example, Crenshaw regards it as a leap to link the idea that help may come from another source, with the idea of a remote deity. He rejects the idea of the king as a witless dupe and the reference to wise women in Israel using sex for desired ends. Crenshaw admits further that Mordecai is not an example of wisdom. Particularly problematic are the nonwisdom elements, such as the nationalistic fervour expressed in the book and not explained in terms of wisdom.

I understand Crenshaw's argument as refuting Talmon's claims and not as a refutation of any argument or claim regarding the presence of wisdom elements in the book of Esther even though it is argued that the Mosaic Torah, for example, was a dominant force in religion at the time of the early Second Temple Period.

3. However, Blenkinsopp (1995:43) argues the militant nationalistic tone and the origins of Purim make it not a very didactic tale within wisdom literature. He thinks the origins lie elsewhere.

4.Blenkinsopp argues that the act-consequence link gave rise to serious theological issues in ancient Israel.

5.For this reason Whybray (1974:5) searches for other criteria, which he found in a study in the use of particular Hebrew words and their cognates in the Hebrew Bible study in the use of particular Hebrew words and their cognates in the Hebrew Bible
in order to discover what the Israelites themselves called wisdom and whom they regarded as wise. 
Katherine Dell (2000:77), warning against the danger of finding wisdom around every corner, proceeds to argue a case for the influence wisdom has in the Old Testament. She (2000:77) regards wisdom as 'part of the fabric of knowledge as experience that shapes the thought' of people such as scribes and prophets. ${ }^{6}$ The question she (2000:93) asks, is whether a text has been influenced by wisdom or constitutes wisdom literature (with the forms, content and context of wisdom) - an independent piece of literature, such as a wisdom novella. She concedes the former, suggesting that wisdom is a much greater yet less defined phenomenon than usually thought of: '[T] here is virtually no part of the Old Testament canon that is entirely free from wisdom influence' (Dell 2000:166). This influence is formative since wisdom was party of everyday speech and a well-known form of selfexpression.

Blenkinsopp (1995:151) argues for a close connection between wisdom and law, contending that Israelite law in its earlier stages can be regarded as a specialisation of clan wisdom. He sees similarities between case law and some proverbial sayings. The publication of Deuteronomy is seen as a significant point in the process of the congruence of wisdom and law. He does not stand hostile to the idea of wisdom in the Joseph narrative, ${ }^{7}$ and by implication in the book of Esther. He is of the opinion that the entire story breathes a sapiential atmosphere and bears comparison with other biblical narratives in which similar themes appear, such as the court narratives. The court was the principal context in which the sages operated; the court setting of many stories is therefore not unusual. In this regard Blenkinsopp (1995:4345) then refers to the book of Esther and the wisdom of Esther and Mordecai, as well as Haman's own undoing, regarding them all as 'a perfect illustration of the sages' teaching on retribution. So the author has certainly made use of the procedures and themes familiar to the teachers of wisdom.'

\section{Law and order}

There seems to be a close connection between wisdom and law when one looks at the issue of retribution. Reward for good actions and punishment for evil deeds is quite central to many Old Testament narratives. In the legal texts the punishment for transgressions is stipulated in detail. The prophets threaten the unfaithful with the power of YHWH if they fail to change their ways. In wisdom, retribution becomes a mechanism for understanding creation, divine intervention and human interaction or participation in the creation order. ${ }^{8}$

Regarding the relationship between law and wisdom, Walther Zimmerli (1964:147) argues that whereas law is regarded as central to the relationship between Israel and

6 .It is significant that the book of Esther does not form part of her discussion in any way. There is no reference to the book in the index to biblical passages.

7.Blenkinsopp (1995:43) finds most of the discussion on the sapiential nature of the Joseph narrative inconclusive and generally unhelpful.

8.See Loader (1986:110). In a Festschrift to Loader, Katharine J. Dell (2010:60) argues that wisdom and creation are closely linked to the concept of order, acknowledging that there is a profound theology of creation in wisdom literature.
YHWH in the midst of history, wisdom has no relation to the history of God and Israel. Wisdom deals with people in their humanity and not in their relationship with the deity. ${ }^{9}$ Wisdom's point of departure is creation and accompanied by a faith of an order that is very practical. It gives wisdom the character of prudence, "the art of steering", knowledge of how to do in life, and thus it has a fundamental alignment to man [sic] and his [sic] preparing to master human life' (Zimmerli 1964:149).

Zimmerli (1964:150) refers to 'sapiential knowledge' which shows how a person gains life in respect for the surrounding world of order, including the order of the divine world. Even the fear of God, the queen of all rules, is subsumed under wisdom. Whereas law is apodictic in nature and curses disobedience, wisdom operates within a framework of counselling which allows some freedom and movement. Wisdom provides insight, but divine authority decrees (Zimmerli 1964:153).

Yet, humanity is authorised by the deity to go out into the world, to observe and to establish the things of the world, such as the order of honesty and dishonesty, truth and falsehood, right doing and wrongdoing (Zimmerli 1964:155). Wisdom has an anthropological starting point and seeks to be 'a human art of life in the sense of mastering life in the framework of a given order in this life', argues Zimmerli (1964:156).

Leo Perdue (1994:121) maintains that wisdom portrays the cosmos as divine creation. It is permeated by justice and constitutes a reality of beauty and life: 'The cosmos is an object of art, a city, a kingdom, even a household in which God, Wisdom, and humans dwell in harmony and joy.' God is the architect of this cosmos: a well-ordered cosmos that sustains and enhances life. Wisdom and law provide order of life so that human beings may experience well-being. Wisdom teaching is rooted in religious piety - a trust in God who created and still sustains the creation order. God is just and transcendent. The God of the sages acts in justice and love by creating, sustaining and blessing the created (Perdue 1994:327). However, human freedom and individual responsibility sometimes collide with divine governance. The human being has the freedom to pursue wisdom or not, and his or her decisions have an impact on their lives and communities.

According to wisdom, there is an order of justice with a creator God who judges the wicked and saves the wise, but it is not an inflexible order of retributive justice in which each word or deed produces an inevitable result:

There was the expectation that good works and wise thoughts led to well-being (understood in a variety of ways, from concrete rewards to less tangible blessings), and there was the expectation that evil and foolishness led to destruction (understood in specific as well as more general terms). However, these expectations are more an affirmation of trust than a dogmatic assertion, more an expression of faith in justice and a righteous God than a blind, incredulous, and naive asseveration, and a more optimistic

9.Zimmerli (1964:147) states that in Proverbs and Ecclesiastes 'the king is never the anointed king of God's people Israel and the son of David, who received God's special promise.' 
affirmation of the goodness of God and his creation than a stern avowal that wickedness and evildoers inevitably reap the harvest of the seed they sow. (Perdue 1994:328)

To Perdue (1994:328) it means that God transcends a legalistic interpretation of retribution. He does not deny the final reckoning, but thinks that God's grace does allow forgiveness and reconciliation.

\section{Order and chaos in the book of Esther}

Crenshaw (1981:66) confirms this hidden fundamental order whereby the wise could secure their existence by acting in harmony with the order. ${ }^{10}$ Accordingly, behaviour or conduct either strengthened the order or threatened to turn it towards chaos. In other words, life was the supreme good (Crenshaw 1981:79). ${ }^{11}$ However, there were two distinct groups that walked on this path of life with two different goals. It was either-or with no middle ground: you were either wise or foolish. The goals were ethically defined: the wise were blameless but fools were evil. Anyone strengthening the order sided with God and would thus participate in the world of order. Anyone diminishing the order and pushing it into chaos was deemed foolish and thus against God (Crenshaw 1981:80).

The point of departure is the order of creation, over which the deity presides. There is a particular order that needs to be followed. Wise actions constitute harmony that will be rewarded by success, over against foolish actions that disrupt the order of creation and lead to failure. Obedience to the rules of wisdom is regarded as recognition of the deity's authority and the person involved is deemed a participant in the creation order. Such a person is considered wise and is rewarded with prosperity (success). Submission to the rules of wisdom means that one accepts the deity's authority. Disregard for the rules of wisdom boils down to rejection of divine authority and constitutes a disruption of the order of creation. Such a person is deemed to be a fool and is rewarded with failure and adversity.

Subsequently, one can construct or presuppose two kinds of worlds in which a story takes place (cf. Deist 1986:102):

- A bad, chaotic world that is out of step with God and where the relationships between God and his people are seriously disturbed and where foolish actions result in chaos or failure.

- An ordered world, the world of wisdom, where the order of creation is maintained and people integrated into creation. There is harmony between God and human beings, actions are always wise and success is therefore guaranteed from the outset.

Applied to the story of Esther and its characters, one can argue the following:

10.Crenshaw affirms this structure in his discussion of the book of Proverbs

11.Such a life, thus Crenshaw (1981:79) was filled with 'a long existence characterized by good health, an abundance of friends, a house full of children, and sufficient possessions to carry one safely through any difficulty.'
Haman lives and dies in the chaotic world. He disturbs the order of creation from the start with his intentions to destroy the Jews. He defies the Jewish god's authority, thereby disrupting the order of creation; the outcome would be his demise or misfortune. He is an example of folly and his humiliation and subsequent death is regarded by the reader as his just deserts. His fall is ironic, since that which he wished upon his enemy befalls him. He ends up on the gallows prepared for Mordecai.

In contrast, Mordecai lives in the ordered world. His portrayal as a Benjaminite constitutes a signifier for the ordered world of the Jewish people in their commitment to Yahweh as their only deity. He acts wisely by sending Esther to the harem in order to become queen. Its usefulness, however, only becomes clear later on. Although Mordecai appears to be callous when he blackmails Esther to conspire with him to save the Jews from destruction, his intervention succeeds. Yet he lives in harmony with YHWH and his faith is rewarded when he assumes Haman's position in the kingdom.

Esther lives on the borderline between the ordered and chaotic world. It is assumed that she lived in the ordered world with her uncle Mordecai, who adopted her. However, by going to the harem, it seems she is pushed into the chaotic world of Persian customs and belief systems. In order to become queen, she has to renounce Jewish customs, especially when asked to hide her identity. Moreover, marriage between Jew and non-Jew was forbidden. When Mordecai encounters her when the decree is proclaimed, she appears indifferent and ignorant about the danger. When Mordecai once again pushes her, she decides to help the Jews. In this it is thought that she acts wisely, as it ensures her survival. She would have died otherwise - either at the hand of Haman who would have been able to carry out his pogrom against the Jews, or at the hand of Jews that might have survived the holocaust and would have vented their hatred towards her, had she also survived.

Thus, the question of whether the retribution in this story as the denouement of a particular plot is the consequence of a wisdom point of view implicit in the story, can be answered affirmatively. But what does that make Esther? When Haman (and by extension his sons as part of the body of people who plagued Israel since the days of their exodus and conquest of Canaan-Amalek) receives his just deserts, does it imply that Esther as executioner of justice is justified in her request for a second day of action?

\section{Justice}

\section{Justice and group responsibility}

In order to understand the issue of justice in the book of Esther, it is perhaps necessary to inquire into the reference to Amalek when the story situates Haman in the plot: he is said to be an Agagite. Agag was the king of the Amalekites in the time of Saul and Samuel. Israel's battle with Amalek dates from the time of the exodus, when Amalek attacked them just before they arrived at Sinai (Ex 17:8-16). In 1 Samuel 
15, Saul is commanded to destroy Amalek completely (1 Sm 15:1-2), killing men and women alike, together with children. Amalek is ordered to be destroyed for their actions whilst Israel was on the move from Egypt. YHWH then told Moses to blot out the memory of Amalek from under heaven. But Saul spared the king as well as the best of the sheep and oxen. Subsequently, YHWH regrets having made Saul king. Samuel then slays the king and the animals.

Ever since the existence of ancient Israel, it seems that Amalek functions as a metaphor for Israel's enemy. It becomes easy in Esther to obliterate Haman and the Persians who took an offensive against the Jews, because their intended violence is simply in line with what is to be expected from the Amalek metaphor - a metaphor that still holds sway in Israel today. Leroy H. Pelton (2005:179) refers to an anecdote of Benjamin Netanyahu, an Israeli Prime Minister. When asked about his anxiety about Iran, one of his advisors replied: 'Think Amalek.' Amalek has become a Hebrew word for an existential threat. ${ }^{12}$

In 'thinking Amalek', however, justice is defined in terms of group responsibility. Pelton (2005:179) describes such killing as group justice similar to the flood and the visiting of plagues upon Egypt. Upon entering Canaan, Joshua did not spare anyone or anything: cities were destroyed and inhabitants killed. David is said to have slain thousands and he would not leave man or woman alive in an attack (1 Sm 27:9). Although there are clear commandments where parents are not regarded as responsible for their children's acts, there are cases where children die because of their parents, for example Job's children. They did not deserve to die. The house of Jeroboam is eradicated because of Jeroboam's idolatry. Leviticus 26:3-33 is very clear on the consequences acts have on a group. Similarly, in Deuteronomy:

If the Israelites obey God and faithfully observeall commandments (and these concern not only ethics, but also ritual and obedience to God), then they shall be granted abounding prosperity ([Dt] 28:1-14). But if they do not heed the Lord, they shall be cursed in the city and in the country, and in their comings and goings. The Lord will let loose against them 'calamity, panic, and frustration in all the enterprises you undertake, so that you shall soon be utterly wiped out'. (Pelton 2005:175)

Retributive justice only makes sense within a community governed by a hierarchical and paternalistic social order based on kinship and patronage (cf. Houston 2010:46). Indiscriminate suffering by real people for sins committed by some of them (not all) can only be explained by the notion of corporate responsibility where evil done in the community is shared by the entire community (Houston 2010:54).

In these terms, justice is defined in terms of just deserts:

12.Pelton (2005:179, quoting a journalist in the New York Times, Eleanor Stump): 'It is amazing that, so many centuries after the battles between the Amalekites and the Israelites, the biblical stories of the Amalekites should still the Amalekites and the Israelites, the biblical stories of the Amalekites should still have a political role to play. $[. .].[A]$ lthough the Amalekites and the Israelites are ancestral enemies, in fact, in the biblical stories, both peoples are part of the same family. The progenito of the Amalekites was born to one of the sons of Esau, the twin brother of Jacob who was one of the ancestors of the whole Israelite people. So, in the stories, the Amalekite people and the Israelite people are cousins, of a sort, at least in their origins.'
We derive satisfaction, no doubt, from a sensed fittingness between deed and desert, from people getting what they 'deserve' (whether that desert be positive or negative). But the sentiment that drives or derives from the application of desert, when set into policy, may violate, rather than do, justice. (Pelton 2005:51)

There are nevertheless cases where deserts do not appear to have any influence on what is regarded as justice. The grounds for justice is utilitarian. In this regard Pelton (2005:102) refers to the divine instruction given to Saul to kill King Agag and all the Amalekites for an assault that took place about two centuries earlier. The only possible connection between the earlier event and the group Saul had to kill was their group membership. One cannot talk here of 'deserts', since the Amalekites to be killed could not have been responsible for the crimes earlier. Thus, what is happening here is revenge and justification in terms of utility:

[I]f the opportunity were left for Israelites to mingle with members of other groups the latter would have a wayward influence on them, and undermine the traditions, culture, code of justice, and other strengths of their own group. (Pelton 2005:103-04)

The disposal of Haman, his ten sons and some Persians can be taken as utilitarian if they were connected to the Amalekites. If Esther did not make doubly sure, the descendants of Haman would have continued to plague the Jews. The suggestion is there because of the reference to Haman's genealogy, but the link between the execution of his evil plan and his own and his sons' deaths seems to weigh stronger in this instance. The utilitarian function of the punishment meted out to Haman and his sons is strengthened when one adds the function of role reversal and the extremes in the narrative: one man causes the demise of his entire group and more than one man dies because of the extremes to which that man went to plan the extermination of an entire group. Says Pelton (2005):

Although it is rarely claimed, in defiance of logic, that individuals not responsible for a crime 'deserve' to be violated for it, attempts are made to claim that those who are to receive benefits or penalties are deserving of, or responsible for, that which they will receive. Arguments are made on the basis of presumed utility as well as deservingness. (p. 104)

\section{Dogville and justice}

How does the film Dogville help one to interpret the denouement of the book of Esther ${ }^{13}$ In both instances one deals with what can be defined as 'rough justice': a justice related to the restoration of balance in a natural system. Any attempt to mitigate the roughness is regarded as arrogance and will end up in more approximate and violent results (Pyper 2010:312).

How can one understand Esther's actions in Chapter 9 of the Book of Esther? Is her request just, wise, and thus tolerable within a system of justice in which retribution plays a large role? Or should one inquire into her actions from a human rights point of view? Does a human rights culture allow for retribution? In the film Dogville, the main character, Grace, 13. Hugh S. Pyper (2010:321-334) employs the film to interpret the book of Amos. 
in the end kills all the town's inhabitants who mistreated her during her sojourn, except the dog - always absent in the film yet turned into life in the last shot when his growl is heard.

Haman ordered the annihilation of the Jewish population. Esther receives the king's permission for the Jews to defend themselves on the fateful day (13 Adar), instilling fear of the Jews (Es 9:2) and of Mordecai (9:3). Five hundred men as well as the ten sons of Haman are killed. Esther then asks the king to have the bodies of Haman's sons hanged in public (9:13) as well as for a continuance of the Jewish defence against the enemy. Subsequently, another 300 men are killed in Susa and 75000 in the rest of the kingdom.

In the book of Esther it seems that justice came with the killing of Haman, the Persians and the hanging of the ten sons of Haman. They all receive their just deserts and the Jews receive their reward and are recompensed for the injustices done to them. ${ }^{14}$ One gets the impression that justice here, in the words of Pyper (2010:325), is a 'sparkling and refreshing stream gladdening the parched fields and providing the righteous with a suitable backdrop for everlasting picnics. ${ }^{\prime 15}$

What seems to be left behind is the psychological damage people may experience, as Paul Draper (2011) formulates it:

the horrible fear that many of the Israelite soldiers would have felt, not of dying or of being injured, but of killing-up close-of hacking into human tissue, of crushing another person's skull while looking into that person's eyes, of slaughtering defenseless children when one's instinct is to protect them. ${ }^{16}$ (p. 201)

Savagery may have been the rule, but it does not mean soldiering was less traumatic and psychologically damaging to soldiers killing other soldiers, or the enemy for that matter.

Although Pyper (2010:325) does not refer to this kind of damage, he makes the point that one should not think that justice operates within a fair system. He makes an important distinction between justice and fairness. They are not the same. He argues as follows:

Justice is a matter of balance. With foolish actions, the world is put into chaos and balance needs to be restored. This stance is in my opinion more or less in line with the traditional wisdom view of order and chaos. BUT where it differs is when the balance is regarded in terms of a pendulum that swings back and removes everything in its way, regardless of being just or unjust: in swinging back it brings 'terror and destruction with it before it eventually settles back to its resting place-and woe betide those, just or unjust, who are in the way as it swings'. (p. 326)

14.According to Greenstein (1987:236-237), the plight of Haman and the Persians in the book, the Jews killing their enemies, is an appropriate reversal: 'A true reversa will place the Jews precisely where their enemies wanted to be, and had their enemies followed Haman's decree, they would have exterminated the defenseless Jews.' Clines (1984:162) calls it a cruel necessity of their own survival.

15.Pyper refers here to the kind of justice Amos aims against where the righteous and the wicked will be swept away.

16.Draper (2011:201) wrote in response to Eleanore Stump's article (2011:179-197) in which she concludes that the story of Amalek is an example of child-rearing that is not easy (2011:197): 'It requires the exercise of agency on the part of the children and their own experience of what makes failure in life. Plainly, forming people, or a whole human species, with an analogous goal is even more difficult and complicated. [...] In the miserable process of formation through experience, one of the things a people can learn is what will not work to enable a people to one of the things a people can
become just, good, and living.'
But to Pyper (2010:326), balance also means that the perpetrator needs to feel what it means to suffer injustice. An eye for an eye is not enough. The victim may have lost an eye in an unprovoked attack, whereas the perpetrator merely loses an eye as the rightful penalty of an attack. The victim's innocence is outraged, but not that of the perpetrator. In order to outrage the innocence of the perpetrator, the eye of one of the children is poked out so that the perpetrator knows what it is to be a victim of an unprovoked and innocent assault.

This mechanism of outrage is operating in Grace's revenge on the inhabitants of Dogville, ${ }^{17}$ but does it operate in the book of Esther? There are two signs: the first is the right to defend oneself if provoked, and the second is the request for a second day of killing and the hanging of the ten sons of Haman. The public display of the killed sons may signify outrage, but Haman will not experience it as he is already dead. The only people who will experience that are the Persians, who are indeed filled with fear. This strategy appears to have been followed by the Bush administration right after $9 / 11$ with its shock and awe campaign, whereby justice is thought to be restored through outrage, 'resting in the ability to frighten, scare, intimidate, and disarm'. ${ }^{18}$

In both Esther and Dogville, death and murder lurks behind the curtains from very early on. Grace is a runaway from her gangster father to whom spraying bullets has become a lifestyle. Esther enters the Persian king's palace as queen just as Haman prepares to set in motion mechanisms that will eliminate the Jewish people, of which Esther is a member. Esther and Grace are beautiful, gracious women who captivate men. Both are victims and end up doing what was supposed to be done to them. Both appear innocent, Esther as young virgin bride, Grace the runaway from a violent father. Yet, can one say of Esther what is said of Grace: that she undergoes a conversion from ultimate martyr to ultimate murderer?

Jacques Lacan (1999:267) writes that martyrs know no pity or fear. Esther knows fear when she is first approached by Mordecai. Grace destructs her own grace by having the town eradicated and shooting Tom execution-style, reminiscent of Hollywood movies where the lonely American cowboy executes justice in his own way with his own gun (cf. Elbeshlawy 2008).

Both appear innocent, without ulterior motive, pure, free of sin, the true innocent victim. Yet Grace's character is quite different from Esther's, giving her final retribution a different coherency than Esther's request of a second day. There is something eschatological about Grace's transformation (Elbeshlawy 2008) 'from the historical victim or the sacrificed

17.Grace's outrage is especially visible in her treatment of Vera. Vera broke Grace's small figurines and said she will stop if Grace does not cry. Similarly, Grace now argued that Vera's children must be executed in Vera's presence and that they should stop when Vera stops crying.

18. Harlan K. Ulmann, James P. Wade, and L.A. Edney, Schock and Awe: Achieving Rapid Domination (Washington DC, National Defence University Press, 1996), page 58 as quoted in Pyper (1994), 'Rough Justice', page 328. Says Pyper: 'The enemy 58 as quoted in Pyper (1994), 'Rough Justice', page 328. Says Pyper: 'The enemy
need to be subjected to an attack that outrages them to the point of complete paralysis of will and numbs them into surrender.' 
Son of God to the revengeful Christ of the Day of Judgment.' The end dialogue suggests an ultimate sacrifice. Behind the father's discourse one may see an allusion to the Christian God who sacrifices himself in order to alleviate sin. The father describes it as 'arrogance' (Elbeshlawy 2008): ${ }^{19}$

Grace: So I am arrogant, I am arrogant because I forgive people.

Father: My God, can't you see how condescending you are when you say that. You have this preconceived notion that nobody can possibly attain the same high ethical standards as you ... I cannot think of anything more arrogant than that. You forgive others with excuses that you would never in the world permit for yourself.

Grace: Why shouldn't I be merciful?

Father: You should be merciful when there is time to be merciful but, you must maintain your own standards, you owe them that. The penalty you deserve for your transgression they deserve for their transgressions.

Grace: They are human beings.

Father: And does every human being need to be accountable for their own actions? Of course they do. You don't even give them that chance, and that is extremely arrogant.

Robert Sinnenbrink (2007) evaluates Grace's actions from the point of view of the failed American dream in which America no longer fulfils its role as a place where the poor and the wretched can pursue their own freedom and happiness in a land of opportunity:

In Dogville, Grace, the stranger outside the law and community, attempts to make a new life for herself, to find freedom and acceptance through the virtues of hard work and self-reliance; but she encounters instead an escalating cycle of exploitation, domination, and violence. She responds to this experience, first, by attempting to accommodate herself to the Dogvilleans' desires, no matter how intrusive; secondly, by attempting to escape from the town, paying ten dollars to be freighted elsewhere as 'dangerous goods'; and thirdly, when these fail - once her escape is betrayed and she is bound in chains and subjected to nightly rapes - by exercising retributive violence that destroys the town and its inhabitants. (n.p.)

Her retribution culminates into a reversal of roles as is the case with Esther, and ends with the fiery destruction of the town and a brutal massacre of the citizens. Where Esther hangs the ten sons of Haman in public, Grace executes her antagonist, Tom, her 'erstwhile benefactor and ultimate betrayer' by shooting him in the head. The only living creature is Moses, the mythical black dog that materialises in the last scene.

Sinnerbrink (2007:n.p.) argues Grace can only proceed with the execution and destruction once she takes her position in the violent social order as the inheritor of her gangster father's criminal organisation. ${ }^{20}$ Similar to Esther, the retribution is effectuated from a position of power, but it is a power that is

19.The dialogue is from the film (Dogville 2004) and the idea from Lattek (2006:113) Justice 'becomes inevitable on the basis of protecting one's own integrity as a moral human being.'

20.Sinnenbrink (2007:n.p.) regards the film as follows: 'The film seeks to unmask the violence and exploitation that founds and sustains the democratic order, which
aims to preserve and administer the life of individuals but reacts with violence aims to preserve and administer the life of individy
when its foundations are exposed or threatened.' associated with death and destruction. It is not benevolent. Is it a question of evil repaying evil, a universal story of corruption that renders a just society impossible to attain? Esther's people, the Jews, are strangers who are excluded from the Persian community. The moment Esther reveals her identity, she exposes Haman's plan as exploitation and violence. Grace too seems to be the excluded stranger. In her case, her acceptance is grounded upon an economy of desire. She exposes the community's repression and they react violently, causing her to counteract with more violence (Sinnerbrink 2007:n.p.).

In the community's response, Grace is exploited and persecuted whilst the injustice is masked by nature and morality. Her response, though, is not 'pure'. She can only react in the way she does when she assumes that position of power from which she initially fled and which took her to Dogville:

She can only take her revenge (for the sake of the future, humanity, her own dignity, as she says) by assuming the corrupted power offered to her by her father, and then having assumed this sociosymbolic mandate, by proceeding to order the destruction of Dogville and its woeful inhabitants. (Sinnerbrink 2007:n.p.)

In order to administer justice, she has to provide for retributive violence (Lattek 2006:112). And she can only achieve the latter if she assumes her place in the symbolic and social order offered by her gangster father. The story is an ambivalent unmasking of the 'will to power that sustains the moral, social, and political order' (Sinnerbrink 2007:n.p.). It seems to me logical to read Esther analogously: she was only able to extort defence for her community because she was queen: it was indeed for a time like this that she became queen in the first place!

\section{Conclusion}

Can Esther be regarded as within her rights to ask for a second day of the continuance of the retribution? Moreover, is she acting with justice or with impunity to request that the ten sons of Haman be hanged? The book of Esther employs a wisdom theme to develop the plot and its denouement. The particular illustration of wisdom is that of role reversal. Haman, the second in command, gets kicked out and the leaders of those he sought to lock out fill his position. However, the role reversal becomes more than a mere change in status. Likewise, in the film Dogville Grace needed to step into her gangster father's shoes in order to achieve justice. The execution of justice is an untidy and messy affair.

The book of Esther is similar in this regard. Esther and Mordecai took Haman's position, but in the end they did to the Persians what Haman intended to do with the Jews. The story provides a logic of good reasons for Esther to ask for retribution and structurally, in the end, in terms of this role reversal and narrative probability, her request makes sense. In terms of narrative fidelity, where all kinds of contexts play a role, her request becomes problematical. The retribution in the story is the way the plot develops and unfolds, and the way in which it develops and unfolds, links up with wisdom 
themes without turning the book itself into a wisdom genre. The wisdom theme plays itself out in terms of the wisdom scheme of the ordered versus the chaotic world. Esther then becomes the instrument by which the fool receives his or her reward.

The reader derives satisfaction from a sensed fittingness between act and consequence. People got what they deserved, but the execution of justice may cause further violation and fail to attain justice. Here the killing and public display of Haman's sons may be problematical. On the one hand, if the assumption is that Haman contemplated the genocide with his house, then their death makes sense. If they are killed merely because they were his sons, then justice can be regarded as utilitarian. This line of thinking is strengthened by the reference to Agag, the Amalekite. In terms of Israel's history (to the present day), an Amalekite is an archenemy that deserves to die. On the other hand, justice is rough, and the fitting response is similar outrage. The perpetrator must experience what the victim experienced. Viewed in this way, the death of Haman's sons is not merely utilitarian, but part of their just deserts in that it expresses Jewish outrage at Haman's evil conspiracy.

\section{Acknowledgements Competing interests}

The author declares that he has no financial or personal relationship(s) which may have inappropriately influenced him in writing this article.

\section{References}

Blenkinsopp, J., 1995, Wisdom and law in the Old Testament: The ordering of life in Israel and early Judaism, Oxford University Press, Oxford. http://dx.doi. org/10.1093/acprof:oso/9780198755036.001.0001

Bremond, C., 1980, 'The logic of narrative possibilities', New Literary History 11, 387 411. http://dx.doi.org/10.2307/468934

Clines, D.J.A., 1984, The Esther scroll: The story of Esther, Sheffield Academic Press, Sheffield.

Crenshaw, J.L., 1981, Old Testament wisdom: An introduction, John Knox, Atlanta.

Crenshaw, J.L., 1995, Urgent advice and probing questions: Collected writings on Old Testament wisdom, Mercer, Macon. PMCid:PMC157288

Deist, F., 1986, 'Verteltekste', in F.E. Deist \& W.S. Vorster (reds.), Woorde wat ver kom bl. 69-102, Tafelberg, Kaapstad.
Dell, K.J., 2000, 'Get wisdom, get insight:' An introduction to Israel's wisdom literature, Darton Longman \& Todd, London.

Dell, K.J., 2010, 'Old Testament theology in ecological focus', in S.F. \& M. Grohmann (eds.), Weisheit und Schöpfung: Festschrift für James Alfred Loader zum 65.Geburtstag, pp. 59-78, Peter Lang, Frankfurt a.M.

Dogville, 2004, Motion picture, Isabella Films/A-Film Entertainment, Amsterdam.

Draper, P., 2011, 'Comments on "the problem of evil and the history of peoples"', in M. Bergmann, M.J. Murphy \& M.C. Rea (eds.), Divine evil? The moral character of the God of Abraham, pp. 198-203, Oxford University Press, Oxford. PMid:21576711

Elbeshlawy, A.F., 2008, 'Dogville: Lars von Trier's desexualized America. "Dogville", Scope: An online Journal of Film and TV Studies 10, viewed 20 June 2012, from http://www.scope.nottingham.ac.uk/article.php?id=991\&issue $=10$

Fisher, W., 1987, Human communication as narration: Toward a philosophy of reason, value, and action, Columbia State University, Columbia.

Garrett, D., 2004, 'This land is your land: Dogville. Reason and redemption, rage and retribution', in Off Screen: Essays, viewed 28 May 2012, from http://www. horschamp.qc.ca/new_offscreen/dogville.htm

Gordon, R.P., 1995, 'A house divided: Wisdom in Old Testament narrative traditions', in J. Day (ed.), Wisdom in ancient Israel: Essays in honour of J.A. Emerton, pp. 94-105, Cambridge University Press, Cambridge. http://dx.doi.org/10.1017/ CB09780511520662.008

Greenstein, E.L., 1987, 'A Jewish reading of Esther', in J. Neusner, B.A. Levine \& E.S. Frerichs (eds.), Judaic perspectives on ancient Israel, pp. 225-243, Fortress Press, Philadelphia.

Houston, W.J., 2010, Justice: The Biblical challenge, Equinox, London.

Lacan, J., 1999, The ethics of psychoanalysis, Routledge, London.

Lattek, M., 2006, 'A reading of "Dogville”', Anamesa. An Interdisciplinary Journal (The Violence Issue) 4, 99-115.

Loader, J.A., 1986, 'Tekste met 'n wysheidsperspektief', in F.E. Deist \& W.S. Vorster (reds.), Woorde wat ver kom, bl. 103-122, Tafelberg, Kaapstad.

Loader, J.A., 1992, 'Das Buch Esther', in J.A. Loader, H.-P. Müller \& O. Kaiser (reds.), Das Hohelied; Klagelieder; Das Buch Esther, bl. 199-280, Vandenhoeck \& Ruprecht, Göttingen.

Pelton, L.H., 2005, Frames of justice: Implications for social policy, Transaction Publishers, New Brunswick.

Perdue, L.G., 1994, Wisdom \& creation: The theology of wisdom literature, Abingdon Press, Nashville. PMCid:PMC1615099

Pyper, H.S., 2010, 'Rough justice: Lars von Trier's Dogville and Manderlay and the book of Amos', Political Theology 11, 321-334. http://dx.doi.org/10.1558/poth. v11i3.321

Sinnerbrink, R., 2007, 'Grace and violence: Questioning politics and desire in Lars von Trier's Dogville', Scan: Journal of Media, Arts and Culture 4, viewed 23 June 2012, from http://scan.net.au/scan/journal/display.php?journal_id=94

Stump, E., 2011, 'The problem of evil and the history of peoples. Think Amalek', in M. Bergmann, M.J. Murphy \& M.C. Rea (eds.), Divine evil? The moral character of the God of Abraham, pp. 179-197, Oxford University Press, Oxford.

Talmon, S., 1963, “'Wisdom” in the book of Esther', Vetus Testamentum 13, 419-455.

Von Rad, G., 1953, 'Josephsgeschichte und Ältere Chokma', Vetus Testamentum, suppl. 1, 121-127.

Whybray, R.N., 1968, 'The Joseph story and Pentateuchal criticism', Vetus Testamentum $18,522-528$.

Whybray, R.N., 1974, The intellectual tradition in the Old Testament, De Gruyter, Berlin.

Zimmerli, W., 1964, 'The place and limit of the wisdom in the framework of the Old Testament theology', Scottish Journal of Theology 17(2), 146-158. http://dx.doi org/10.1017/S0036930600005780 